\title{
SOFT SUBGRADE STABILIZATION WITH QUARRY DUST-AN INDUSTRIAL WASTE
}

\author{
U Arun Kumar ${ }^{1}$, Kiran B. Biradar ${ }^{2}$ \\ ${ }^{1}$ Associate Professor, Civil Engg. Dept, GMRIT Rajam, AP, India \\ ${ }^{2}$ Post graduate student, Civil Engg. Dept, GMRIT, Rajam, AP, India
}

\begin{abstract}
Performance of Flexible Pavement depends on the functions of the component layers especially Subgrade. Subgrade is compacted layer of soil provide the lateral support to the pavement. Construction over soft Subgrade affects the performance of pavement and results in shorter life of pavement. The typical approach of stabilization of soft Subgrade is to remove the soft soil, and replace it with soil of high strength. The high cost of replacement of poor soil has caused highway agencies to assess alternative methods to construct the highway over soft Subgrade. One approach is to improve the properties of soil is with addition of the waste materials. Soil stabilization is one of the most suitable alternatives which are widely used in pavement construction. Soil stabilization technique used to improve the engineering properties of soil such as strength and stability. Quarry dust is one of the admixtures utilized for effective ground improvement technique over weak Subgrade soil deposits. In this study Quarry Dust has been selected as a Stabilizer. Laboratory tests were conducted on soil with various percentage of Quarry Dust. Atterberg limit and compaction test were carried out on both unmodified and modified soil. California bearing ratio (CBR) test was performed to determine the strength properties of the Soil-Quarry dust mixtures. Higher CBR values of soil-quarry dust mix extent their potential for use as a Subgrade for flexible pavement.
\end{abstract}

Keywords - Soft Subgrade soil, Quarry dust, Stabilization, CBR $* * *$

\section{INTRODUCTION}

Transportation is necessary for the proper functioning and development of economic activities for any country, which involves production and distribution of goods and services from one place to other. Performance and life of road network is generally depending upon the design and construction. Subgrade is generally made up of locally available natural soils. The strength and performance of a pavement is dependent on the load-bearing capacity of the Subgrade soil. In case of poor soil in construction site, the poor soil can be removed or replaced with the soil of high strength. Design of pavement is depend upon the strength of the subgrade soil, which affects the thickness of pavement ultimately increase the cost of construction. Improvement in load bearing capacity of soil will improve the load-bearing capacity of pavement and thus, pavement strength and its performance.

Aggregate crusher units produce large quantities of quarry dust, a waste product, produced during crushing of Gravel and rock. Disposal of these large quantities of quarry dust produces serious problem in environment and health hazard. There is requirement to utilize these waste materials. Quarry dust can be used in very large quantity, reducing the total cost of construction in addition to providing a solution to an environmental problem.

Sridharan and soosan et.al (2005) identified that quarry dust manifest high shear strength and is beneficial for its use as a geotechnical material. Sabat et.al (2012) conducted compaction, tri-axial and durability tests on lime stabilized expansive soil-quarry dust mixes. Satyanarayana, et al
(2013) has studied that the strength characteristics of compacted crusher dust and Crushed Stone mixes through a series of CBR tests by varying the crusher dust. Ramadas and Kumar et.al (2010) reported that the combination of fly ash and stone dust found to be suitable to reduce swelling and increase the strength of expansive soil. Onyelowe Ken et.al (2012) exposes the qualities and applications of quarry dust as admixture during soil improvement and for a more economic approach. Agrawal and gupta et.al (2011) reported that the potential use of marble dust as stabilizing additive to expansive soil, which involves the determination of the swelling potential of expansive soil in its natural state as well as when mixed with varying proportion of marble dust.

\section{MATERIALS}

\subsection{Soil}

The soil sample used for this study is collected near Chaitanya Techno School, Srikakulam road, Rajam, Srikakulam District, Andhra Pradesh.

Table 2.1 Geotechnical Properties of Soil Sample

\begin{tabular}{|l|l|}
\hline Liquid limit (\%) & 47.70 \\
\hline Plastic limit (\%) & 25.65 \\
\hline Plasticity index & 22.05 \\
\hline Percent finer & 65.02 \\
\hline IS classification & CI \\
\hline OMC $(\%)$ & 15.80 \\
\hline MDD $\left(\mathrm{kN} / \mathrm{m}^{3}\right)$ & 18.04 \\
\hline CBR Soaked & 1.82 \\
\hline
\end{tabular}




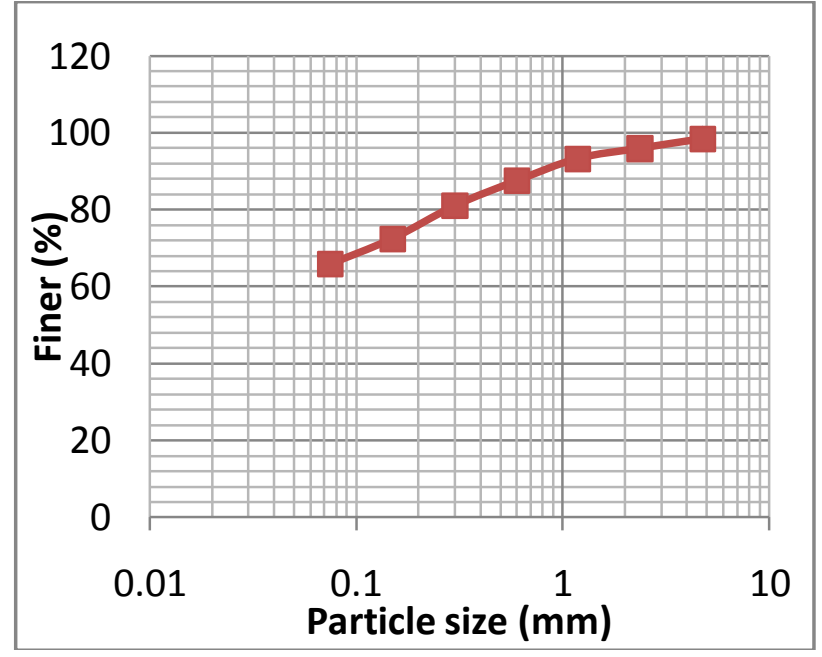

Fig.1 Grain Size Analysis for Unmodified Soil

\subsection{Quarry Dust}

The quarry dust used was collected from a local quarry at Pondur, Srikakulam District, Andhra pradesh. Experiments were conducted on the samples blended with waste materials at different percentages.

Table 2.2 Properties of Quarry Dust

\begin{tabular}{|l|l|}
\hline Specific gravity & 2.68 \\
\hline OMC (\%) & 8.30 \\
\hline MDD $\left(\mathrm{kN} / \mathrm{m}^{3}\right)$ & 17.02 \\
\hline Gravel Size particles (\%) & 1 \\
\hline Sand Size particles (\%) & 97 \\
\hline Fine Size particles (\%) & 2 \\
\hline
\end{tabular}

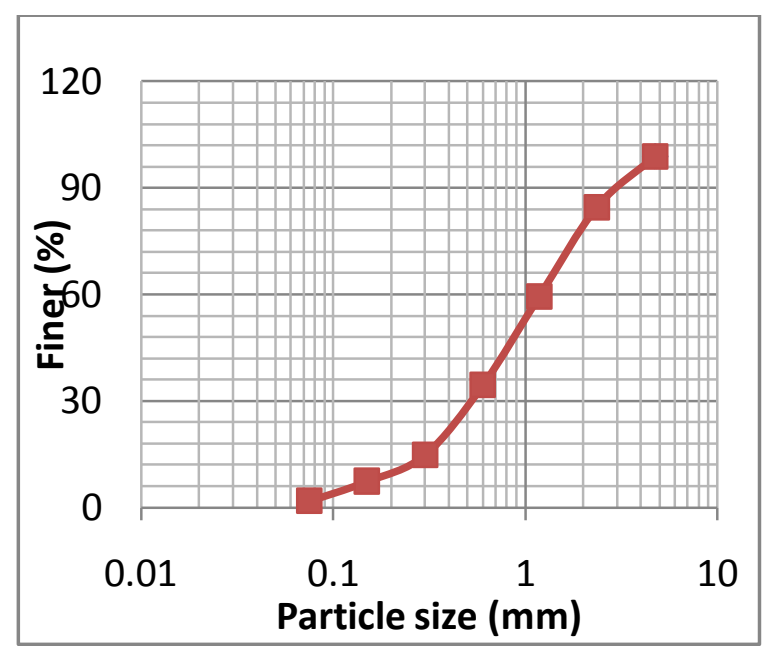

Fig.2 Grain Size Analysis for Quarry Dust

\section{RESULTS AND DISCUSSION}

Experiments were conducted on the samples blended with varying percentages of Quarry dust to determine the index and engineering properties of the modified soils.

\subsection{Plasticity Characteristics}

The liquid limit and plasticity index of the conventional soil shows that the soil is a clay with intermediate plasticity (CI) as per the plasticity chart given in IS: 2720 (part 5)-1985.

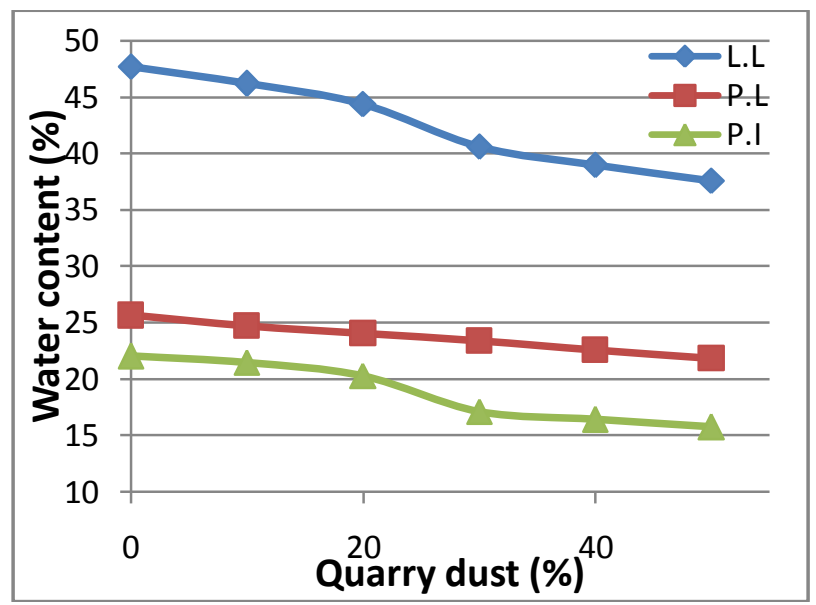

Fig. 3 Plasticity Characteristic of Soil-Quarry Dust Mixes

Table 3.1 Variations of L.L, P.L and P.I for Soil+Quarry Dust Mixes

\begin{tabular}{|l|l|l|l|}
\hline $\begin{array}{l}\text { Soil+Quarry dust } \\
(\%)\end{array}$ & $\begin{array}{l}\text { L.L } \\
(\boldsymbol{\%})\end{array}$ & $\begin{array}{l}\text { P.L } \\
(\boldsymbol{\%})\end{array}$ & $\begin{array}{l}\text { P.I } \\
(\boldsymbol{\%})\end{array}$ \\
\hline $100+0$ & 47.70 & 25.65 & 22.05 \\
\hline $90+10$ & 46.2 & 24.72 & 21.48 \\
\hline $80+20$ & 44.40 & 24.09 & 20.31 \\
\hline $70+30$ & 40.6 & 23.44 & 17.16 \\
\hline $60+40$ & 39 & 22.57 & 16.43 \\
\hline $50+50$ & 37.6 & 21.83 & 15.77 \\
\hline
\end{tabular}

\subsection{Compaction Characteristics}

The moisture content-dry density relationship of a given soil is determined by standard proctor test as per IS 2720 (Part7)-1980 (REAFFIRMED-1997).

Table 3.2 Variations of OMC and MDD for Soil+Quarry Dust Mixes

\begin{tabular}{|l|l|l|}
\hline $\begin{array}{l}\text { Soil+Quarry dust } \\
(\%)\end{array}$ & $\begin{array}{l}\text { OMC } \\
(\boldsymbol{\%})\end{array}$ & $\begin{array}{l}\text { MDD } \\
\left(\mathbf{k N / m ^ { 3 }}\right)\end{array}$ \\
\hline $100+0$ & 15.80 & 18.04 \\
\hline $90+10$ & 14.60 & 18.26 \\
\hline $80+20$ & 13.90 & 18.48 \\
\hline $70+30$ & 12.80 & 18.74 \\
\hline $60+40$ & 11.50 & 19.10 \\
\hline $50+50$ & 10 & 18.84 \\
\hline
\end{tabular}




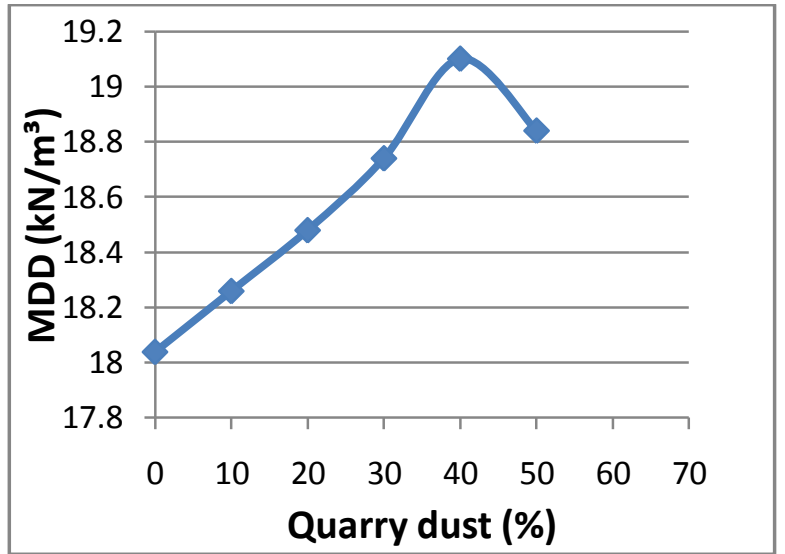

Fig.4 Effect of Soil +Quarry Dust Mixes on MDD

Reduction in percentage of void causes increase in MDD of soil up to $40 \%$ of Quarry dust. Furthermore increase in Quarry dust reduces MDD due to more occupation of quarry dust.

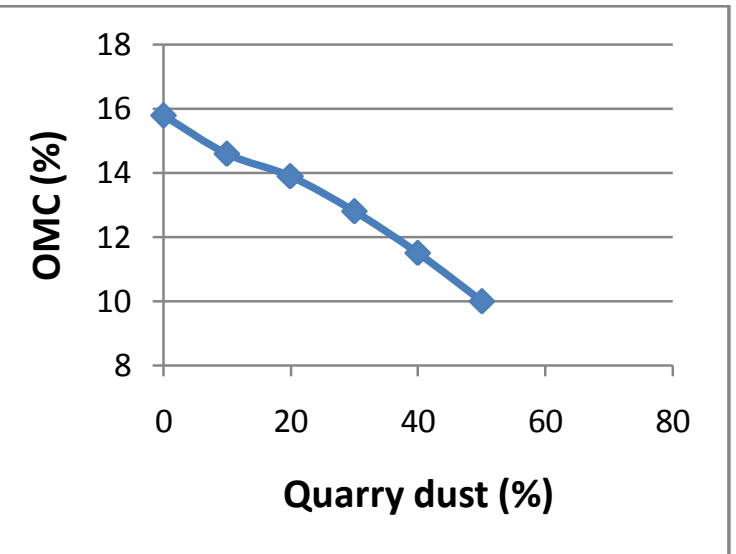

Fig.5 Effect of Soil +Quarry Dust Mixes on OMC

\subsection{California Bearing Ratio}

CBR tests were conducted on samples compacted to optimum moisture content obtained from the standard proctor test as per IS 2720 (Part-16)-1987.

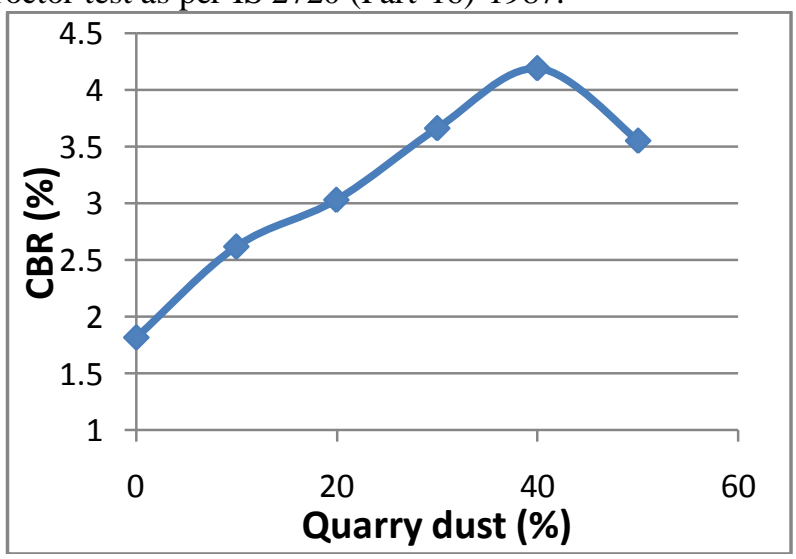

Fig.6 Variation of CBR with for Soil +Quarry Dust Mixes

CBR value of Soil is increases as percentage of Quarry dust increases upto $40 \%$, furthermore increase in Quarry dust reduces the $\mathrm{CBR}$ value. As higher percentage of reduction in void ratio affects in the higher CBR value in Soil+ (40\%) Quarry dust mixes.
Table 3.3 CBR Value for Soil +Quarry Dust Mixes

\begin{tabular}{|l|l|}
\hline Soil+Quarry dust (\%) & CBR (\%) Soaked \\
\hline $100+0$ & 1.82 \\
\hline $90+10$ & 2.62 \\
\hline $80+20$ & 3.03 \\
\hline $70+30$ & 3.66 \\
\hline $60+40$ & 4.19 \\
\hline $50+50$ & 3.55 \\
\hline
\end{tabular}

\section{CONCLUSIONS}

The experiment conducted to study the effect of Quarry dust addition on conventional soil reveals the following.

1. The addition of the Quarry dust to the soil reduces the clay content and thus increases in the percentage of coarser particles, reduces the Liquid limit by $26.86 \%$ and plasticity index by $28.48 \%$ of unmodified soil.

2. Optimum moisture content of soil is decreased by $36.71 \%$, with increase in Percentages of Quarry dust.

3. Maximum dry density of soil is increased by $5.88 \%$ by addition of (40\%) Quarry dust.

4. It is also identified that addition of $(40 \%)$ Quarry dust yield high CBR value.

\section{REFERENCES}

[1]. Akshaya Kumar Sabat, "A Study on Some Geotechnical Properties of Lime Stabilised Expansive Soil -Quarry Dust Mixes," in IJEED, (2012), ISSN: 2249-6149, Issue 2, Vol.1, PP 42-49.

[2]. Moses.G.K, Saminu. A “Cement Kiln Dust Stabilization of Compacted Black Cotton Soil," in EJGE, Vol. 17 [2012], Bund. F, 825-836.

[3]. Onyelowe Ken C, Okafor F.O, Nwachukwu D, "Geophysical Use of Quarry Dust (as admixture) As Applied to Soil Stabilization and Modification-A Review," in ARPN, (2006), Vol. 1, No. 1, (2012), ISSN: 2305-493X.

[4]. Ramadas T.L, Kumar N. Darga, Aparna G, "Swelling and Strength Characteristics of Expansive Soil Treated with Stone Dust and Fly ash," Indian Geotechnical Conference 2010.

[5]. Sridharan A, Soosan T.G, Babu T. Jose, Abraham B.M, "Shear strength studies on soil- quarry dust mixtures," in SPRINGER, Geotechnical and Geological Engineering (2006), 1163-1179.

[6]. Satyanarayana P.V.V, Raghu P, Ashok Kumar R, Pradeep N, "Performance of crusher dust in high plastic gravel soils as road construction material," in IOSR-JMCE, (2013), e-ISSN: 2278-1684, p-ISSN: 2320-334X, Vol. 10, Issue 3, PP 01-05.

[7]. Satyanarayana P.V.V, Prem Teja R, Harshanandan T, Lewis Chandra K, "A Study On The Use Of Crushed Stone Aggregate And Crusher Dust Mixes In Flexible Pavements," in IJSER, Vol. 4, Issue 11, (2013), ISSN:2229-5518, PP 1126-1136. 
[8]. Vinay Agrawal, Mohit Gupta,"Expansive Soil Stabilization Using Marble Dust," in International Journal of Earth Sciences and Engineering, ISSN 0974-5904, Volume 04, No 06 SPL, October 2011, pp 59-62.

[9]. IS 2720: Part 5: 1985 Methods of Test for Soils - Part 5:

Determination of Liquid and Plastic limit.

[10]. IS 2720: Part 7: 1987 Methods of Test for Soils - Part 8: Determination of water Content and Dry Density Relation Using Light Compaction.

[11]. IS 2720: Part 16: 1987 Methods of Test for Soil - Part 16: Laboratory Determination of CBR. 